\title{
Setting the Stage for Developing Pre-Service Teachers' Conceptions of Good Science Teaching: The Role of Classroom Videos
}

\author{
Siu Ling WONG (aslwong@hkucc.hku.hk), Benny Hin Wai YUNG, \\ Man Wai CHENG, Kwok Leung LAM, Derek HODSON \\ Faculty of Education, The University of Hong Kong, Hong Kong SAR, China \\ Wong, S.L., Yung, B.H.W., Cheng, M.W., Lam, K.L., Hodson, D. (2006) Setting the \\ stage for developing pre-service teachers' conceptions of good science teaching: The role \\ of classroom video. International Journal of Science Education, 28(1), 1-24.
}

This paper reports findings about a curriculum innovation conducted at The University of Hong Kong. A CD-ROM consisting of videos of two lessons by different teachers demonstrating exemplary science teaching was used to elicit conceptions of good science teaching of student teachers enrolled for the oneyear Postgraduate Diploma in Education ${ }^{1}$ (PGDE) at several stages during the programme. It was found that the videos elicited student teachers' conceptions and had impact on those conceptions prior to the commencement of formal instruction. It has extended student teachers' awareness of alternative teaching methods and approaches not experienced in their own schooling, broadened their awareness of different classroom situations, provided proof of existence of good practices and prompted them to reflect on their current preconceptions of good science teaching. In several ways, the videos acted as a catalyst in socializing the transition of student teachers from the role of student to the role of teacher.

\footnotetext{
${ }^{1}$ Postgraduate Diploma in Education (PGDE) is the standard form of pre-service teacher education in Hong Kong. It provides qualified teacher status within Hong Kong SAR. Student teachers enrolled for the PGDE have completed a relevant undergraduate degree.
} 


\section{Introduction}

Teachers and student teachers often question the relevance of pre-service teacher education programmes, criticizing them as being too abstract, theoretical and remote from the 'real world' of the classroom (Barone et al. 1996, Bryan and Abell 1999). Courses are often criticized for presenting abstract, systematized knowledge in a decontextualized way, as though appropriate knowledge for informing teaching is independent of specific educational settings. Not surprisingly, therefore, student teachers often rate teaching practice much higher than other components of the course (Anderson 1997) and regard this experience as the most powerful influence on their views of teaching (Zeichner and Gore 1990), despite the emotional stress of these first classroom experiences. In consequence of these and related criticisms, there has been a move in the United Kingdom towards school-based pre-service teacher education (Korthagen and Kessels 1999). We regard this development as misguided, and in taking this position we are mindful of Broadfoot's (1992) assertion that

Teacher expertise cannot be acquired simply by doing, any more than learning to be an effective medical practitioner can be achieved only by observation and practice (p. 49).

University study provides a venue for reflection, critique, theory building and acquiring other perspectives. Without a robust body of theoretical knowledge, student teachers are ill-equipped to resist institutional constraints on their teaching (overcrowded syllabuses, examination pressures, inadequate laboratory facilities, and the like) and unable to resist the sometimes 'anti-intellectual' climate of school staffrooms. They often revert to teaching as they were taught (Calderhead and Robson 1991, Hoy and Murphy 2001) or they are socialized into conformity with the routines of other teachers (Zeichner and Gore 1990, Munby et al. 2000) - and sadly not always with the practices of those teachers 
whom we would wish them to emulate. Critique, reflection and theory are 'tools of resistance' in the struggle between ideals and the dictates of established practice, though these 'tools' cannot be simply and straightforwardly passed on by teacher educators or easily assimilated by student teachers.

Among the problems confronting teacher educators are the often quite radical differences in conceptions of teaching and learning between educators and the consequent perception of many student teachers that educational theories are impractical. It is our contention that teacher educators need to ascertain, and sometimes to challenge students teachers' preconceptions about teaching and learning lest their personal experiences of school (as a student), rather than more fundamental educational considerations, become the basis for lesson planning during teaching practice, and beyond.

It is tempting to draw parallels between the process of constructing conceptions of good teaching and learning and the process of conceptual change in learning science (Gunstone et al. 1993, Abell et al. 1998). First, extensive research over the past 20-25 years has shown that students coming into the science classroom often possess preconceptions about natural phenomena, many of which are in conflict with accepted scientific concepts and highly resistant to changes, even after formal instruction (Driver et al. 1985, Osborne and Freyberg 1985). Second, Posner et al. (1982) argue that conceptual change will only occur when students feel dissatisfied with their current conceptions and have access to alternatives they perceive as intelligible, plausible, and fruitful. In consequence, it is important for science teachers to begin by identifying the preconceptions of their students. Similarly, prospective teachers begin programmes of teacher education with preconceptions about teaching and learning which may also be highly resistant to change (Duit and Treagust 2003). Gow and Kember (1993), on the basis of research with university teachers, make the point that altering conceptions of 
teaching and learning is not a task to be underestimated, a finding echoed by BoultonLewis et al. (2001) in their study of secondary school teachers. It is our contention that teacher educators need to be aware of these preconceptions and to respond appropriately to them, and they need to be cognizant of how conceptions of good science teaching can be influenced by well-chosen educational experiences.

This paper reports some findings about a curriculum innovation at The University of Hong Kong (Yung et al. 2003) which aims to probe, develop and enrich student teachers' conceptions of good science teaching at different stages of the pre-service teacher education programme through the use of classroom videos of exemplary science teaching $^{2}$. As a variant on the usual approach of showing and discussing these videos during class time, we provided our student teachers with a CD-ROM, consisting of the lesson videos together with background notes about the lessons and the students, prior to the commencement of our teacher education programme. As the first step in a constructivist pedagogy designed to bring about conceptual change about teaching and learning science, we identify their preconceptions about science teaching through elicitation of their views before and after watching the videos.

\section{Theoretical underpinnings}

\section{Learning as conceptual change}

Constructivist pedagogy involves a series of steps designed to bring about conceptual change: identify students’ preconceptions; create opportunities for them to explore and test their preconceptions; provide stimuli for students to develop, modify or change their views; support attempts to rethink and reconstruct their views. Based on the conditions

\footnotetext{
${ }^{2}$ Teaching shown in the videos was categorized as exemplary by the participants of an earlier project funded by the HKSAR Government's Quality Education Fund. The participants included science educators, curriculum planners and practising science teachers of diverse backgrounds.
} 
for conceptual change put forward by its originators (e.g., Posner et al. 1982, Hewson 1981), Hewson and Thorley (1989) suggest that for effective conceptual change, teachers should be able to diagnose students' conceptions and monitor the status of old and new conceptions in the minds of the students in terms of intelligibility, plausibility and fruitfulness. They also propose that students should be assisted in becoming aware of their own processes of conceptual change, and adept at monitoring and managing them.

In recognizing similarities between the process of constructing conceptions of teaching and learning and the process of conceptual change in learning science (Gunstone et al. 1993, Abell et al. 1998), we begin by diagnosing our student teachers’ preconceptions about teaching. It is important to emphasize that this is the first but not the only step in bringing about conceptual change, and to recognize that the conceptual change model put forward in the early 1980's is overly rationalistic and neglectful of other factors impacting learning. For example, Solomon (1987) points out the striking neglect of the social dimension of the learning, while Pintrich et al. (1993) highlight the absence of a motivational dimension and the failure to consider contextual factors that affect learning. In their review of the historical development of the notion of conceptual change in over the past three decades, Duit and Treagust (2003) summarize the trend towards multi-perspective frameworks in addressing the complexity of the teaching and learning processes.

The importance of examining student teachers’ preconceptions about teaching was highlighted by Clark (1988), more than a decade and a half ago.

Students begin teacher education programs with their own ideas and beliefs about what it takes to be a successful teacher. These preconceptions are formed from thousands of hours of observation of teachers, good and bad, over the previous fifteen or so years. Undoubtedly, students' conceptions of 
teaching are incomplete... With this in mind, a thoughtful teacher educator might ask: What are the preconceptions about teaching and learning held by our students? (p.7)

Central to Clark's argument is that all student teachers bring with them into preservice teacher education courses a set of preconceptions about teaching and learning which needs to be carefully analyzed and understood from a developmental perspective. Not only are these conceptions an interesting focus for research, they constitute a key starting point in building an appropriate teacher education programme and a key element in the armoury of the thoughtful teacher educator. Encouraged by Schön’s (1983) seminal work and by recent research efforts showing the usefulness of reflection as a tool for understanding science teacher thinking and development (e.g., Abell et al. 1998), we recognize the importance of student teachers adopting a similar stance with regard to their professional learning. Thus we have incorporated into this curriculum innovation the element of student reflection on their conceptions of teaching.

Bridging the theory-practice gap through the use of exemplary cases

It is imperative that what we do in teacher education programmes bridges the theorypractice gap. Our task is to find ways of 'translating' theory and research-based knowledge and beliefs into appropriate and effective action, to find ways of making preservice education experiences more like the 'real world' of the classroom while retaining the capacity to be critical and reflective (Carter 1993). One way of achieving this delicate balance is through the use of case methods (Colburn and Tillotson 1998, Harrington 1995, Koballa and Tippens 2000, 2004, Levin 1995, Louden and Wallace 1996, Tobin and Fraser 1989, Greenwood and Parkay 1989, Kowalski et al. 1990, Silverman et al. 1996) - 
methods that have long been a mainstay of education programmes in law and medicine (Merseth 1991).

In order to facilitate our student teachers to analyze, understand, reflect and express their views on good science teaching in some detail, we provided them with videos of exemplary cases of science teaching as one of the prompts. The exemplary cases were selected from the database of an earlier project ${ }^{2}$ in which over 100 hours of raw footage of exemplary and innovative practices in science teaching at the secondary level was established. The videos were not intended to be dogmatic in promoting what we consider to be good science teaching but to be provocative in eliciting what our student teachers consider to be good science teaching. In other words, by inviting student teachers to provide explanations for why they regard particular teaching practices featured in the videos as good (or not), we stimulate them to reveal their conceptions of good teaching. The opportunity to engage with authentic classroom episodes via the videos is a powerful stimulus to the articulation of the abstract elements constituting conceptions of teaching (Gao and Watkins 2002). Our particular use of exemplary cases is based on the following conclusions from Black and Atkin's (1996) critical examination of 23 educational reforms in science, mathematics and technology education in 13 countries:

- Exposure to other ideas broadens teachers' awareness of possibilities for change and fosters a sense that alternatives are available.

- Existence proof of new methods under normal classroom conditions gives moral support to teachers and challenges them.

- Demonstration of actions, reflecting the new ideas, in a real context deepens teachers' understanding. Also, such modeling strengthens the proof of existence.

Exemplary case teaching has been found particularly appropriate in preparing teachers for reform-based teaching (Putnam and Borko 1997) because the opportunity for 
teachers to experience workable alternatives to conventional practice in actual classroom settings is often quite limited. More importantly, teaching focused on exemplary cases is able to utilize the situated learning theories proposed by scholars such as Lave and Wenger (1991) and Rogoff (1990). These learning theorists propose that learning is situated in authentic contexts which allow learners to participate in communities of practice. They claim that because action (and the knowledge that derives from it) is situation-specific, and because rule-following alone does not help solve situated problems, learning must occur in social settings that closely match the target performance setting. Like Putnam and Borko (2000), we find this notion particularly well-suited to teacher learning. The authentic context is the classroom where student teachers engage in an apprenticeship through which they join, peripherally at first and more fully as times goes on, the community of science teaching practice.

As pointed out by Abell and Cennamo (2004), the situated learning perspective creates the ultimate paradox for science teacher preparation: we want our student teachers to observe, develop and enact reform-minded practice in real classrooms, yet the kinds of classrooms in which we would like our student teachers to serve their apprenticeships are few and far between. In short, exemplary sites for modeling best practice in science education can be difficult to find. The provision of classroom videos of exemplary science teaching in this project is intended to meet this shortfall.

Cases help student teachers to build knowledge through vicarious experience of authentic classroom situations. It is not abstract theory, detached from the real world of the classroom. Nor is it the complex and emotionally stressful real world of the classroom, where classroom decision-making occurs largely at the unconscious level or at what Roth et al. (1999) call the 'gut response level'. Cases are located at the nexus of theory and practice: they provide a 'window' into the classroom, enabling students to confront real 
life situations in a secure, supportive, critical and reflective environment; they assist students in building their own conceptions of good science teaching by stimulating reflection on their own experiences (as student and as teacher) and the experiences of others (the teachers in the cases). Because cases focus on authentic teaching and learning situations, student teachers are more receptive to the perspectives and practices depicted in them than they would be to the same ideas presented in lecture form.

\section{Professional development through the use of videos}

Recent advances in video technology have led to increasing incorporation of videos and multimedia materials into pre-service and in-service teacher education (Abell et al. 1998, Hewitt et al. 2003, Louden and Wallace 1996, Sherin and Han 2004, van den Berg 2001), commonly for demonstration of good practices or as a reflection tool for teacher professional development (Brophy 2004). When presented in video and multimedia format, cases offer enormous scope for representing the complex and ever-changing contexts in which teachers have to make frequent on-the-spot classroom decisions (Bencze et al. 2001, 2003, Copeland and Decker 1996, Crooks and Gifford 1992, Hewitt et al. 2003). By capturing the interplay of social, cultural, situational and psychological factors, videos can give teachers powerful insight into what it is like to 'be there'. Of course, video cases can never fully replicate the complexity of working in a real classroom because the student teacher herself/himself is only present as a 'distant observer'. In this role as distant observers, student teachers are able to 'stand back' and to consider alternative perspectives in ways that are not possible in the hurly-burly 'real world' of the classroom. Also, watching someone else does not necessarily ensure that student teachers will reflect on their own beliefs and practices (Abell et al. 1998). In that sense, video cases can be too distant. Focused activities based on the video cases are often 
necessary to ensure that distant observers become critical, reflective and analytical observers. Used in this way, video cases constitute a powerful means to present student teachers with alternative perspectives and practices, stimulate them to look at events from the students' perspectives as well as the teacher's, and to become much more conscious of their own knowledge, beliefs, values and feelings (Harrington 1995, Marx et al. 1998) by considering how they would have acted in a similar situation.

Video cases fit very well into the kind of constructivist approach to pre-service teacher education advocated by Rodriguez (1998) and Rubba (1992), in which student teachers are (i) stimulated to articulate their current conceptions of teaching and learning, (ii) encouraged to explore these ideas and to test their robustness in a variety of circumstances, (iii) presented with alternative views that go beyond their own experiences (Sanger 1990) and (iv) supported in modifying and developing their ideas to accommodate their increasingly sophisticated understanding of the complexity and fluidity of science classrooms. While, on the one hand, this video-based project aimed to provide student teachers with concrete and practical examples of how to realize some of the goals of recent Hong Kong curriculum reform by introducing them to the exemplary cases, we also agree with Wilson and Berne's (1999) comment that "teacher learning ought not be bound and delivered but rather activated” (p.194). In other words, the goal of teacher professional development should be to increase teachers' awareness of the potential for learning rather than to present them with a prepackaged set of new pedagogical strategies. Thus, our intention is that the student teachers will make use of the exemplary cases:

- as a source of models of practice to apply and test in their own classroom;

- as examples of practice that can be compared to their own existing practices and/or previous experiences; and particularly, 
- as a set of ideas to be debated and as a springboard to reflection on their existing conceptions of good science teaching.

This concurs with Cochran-Smith's (2003) view of professional development as a process of helping teachers to develop an attitude of inquiry toward their own learning. In particular, we believe, if teachers are presented with dilemma-focused cases, they will naturally be drawn into an inquiry mode.

\section{The study}

\section{Participants}

Student teachers enrolled in the science major methods course of the Postgraduate Diploma in Education ${ }^{1}$ at The University of Hong Kong were invited to attend a briefing session two weeks before the course formally began. We explained that the purpose of the study was (i) to allow participants and the science (physics, chemistry and biology) methods course instructors to better understand and monitor their conceptions of good science teaching at different stages of the course, and (ii) to help them to become reflective practitioners. We further explained that the tasks they engaged in during this study would not contribute towards their final grade. All the 88 science student teachers agreed to participate. During this briefing session, each student teacher was asked to list features of what they consider to be good science teaching by filling in a task sheet (Task 1, see appendix I). These data represent their 'pre-video entry conception'. Each student teacher was then given a CD-ROM consisting of videos of the two lessons of exemplary science teaching.

\section{Lesson videos}

The two lesson videos were selected from the archive and edited by making reference to the theoretical framework used by Kember (1997) which synthesizes and re- 
conceptualizes studies on conceptions of teaching. Our goal was to produce videos with sufficient detail and representative variety within the five dimensions of the Kember's framework:

- the essential features of learning and teaching

- the roles of the student and teacher

- the aims and expected outcomes of teaching

- the content of teaching, and

- the preferred styles and approaches to teaching.

Although it was necessary to limit the total duration of the video clips to within one hour, so as to ensure a reasonable total viewing time, strenuous efforts were made to maintain the integrity, flow and general essence of the lessons. Two independent science educators were asked to validate the contents of the videos against Kember's framework to ensure a full range of video snippets covering all the five dimensions.

Lesson I is a 70-minute lesson (edited to 40 minutes) taught by Mark on the subject of density, delivered to a class of 12-year-old students (junior secondary one) in a laboratory. This is the last lesson of the unit "Matter as Particles". In previous lessons, students had learnt about the particle theory and gas pressure, and had been introduced to some concepts relating to density. The aim of Mark's lesson is to consolidate and elaborate on the concept of density by involving students in hands-on practical work. Lesson II is a 45-minute lesson (edited to 20 minutes) by Luke on the processes of scientific inquiry, given to a class of 12-year-old students (in a different school) in a nonlaboratory setting. In contrast to Mark's class, the students are relatively poor in terms of academic attainment. This lesson took place in the first month of the academic year after the students had had their first laboratory experience. It followed up an earlier laboratory session in which the students were introduced to various common laboratory apparatus 
through a simple observational activity focused on temperature change as water is heated. The teacher made use of this activity to introduce and highlight several important steps in scientific inquiry.

These two lessons demonstrated a range of non-traditional, reform-advocated teaching practices such as hands-on practical work, emphasis of process skills, teacher modeling of thinking processes, encouragement of pupil talk, infusion of nature of science, and so on, with the intention of challenging the teacher-centred, transmissive teaching approach which most of our student teachers had experienced during their own schooling, and might perceive as natural and normal.

The student teachers were asked to review the CD-ROM at home and to identify both the good features of the lessons and any areas they regard as in need of improvement by completing Task 2 (see appendix II). In order not to bias their views, they were told that the videos were representative of 'ordinary science teaching' currently occurring in mainstream schools. Although the videos of the particular lessons were used because they demonstrated numerous good science teaching elements, it proved impossible to cover every good feature within the confines of the videos. To address this limitation, the student teachers were asked to list other essential features of good science teaching which had not been exhibited in the videos. These data represent the student teachers' 'postvideo entry conception’.

\section{Follow-up interview}

Based on our analysis of the 'pre-video entry conception' and 'post-video entry conception' collected in Task 1 and Task 2, we selected a subgroup of student teachers for individual interview to elaborate their conceptions of good science teaching and, when necessary, clarify what had been written down on the task sheets. The selection criteria 
ensured that student teachers with conceptions of good science teaching ranging from the least sophisticated to the most elaborated were interviewed. We were particularly interested in those student teachers who indicated in Task 2 that the video had had significant impact on their conception of good science teaching. In addition, those student teachers with a special academic background (e.g. a master's or doctoral degree) or some previous teaching experience were included. A total of 42 student teachers were invited for interview before the commencement of our pre-service programme. These entry interviews lasted for 45 to 80 minutes. The interview data were translated from Cantonese to English and subsequently transcribed. When students' questionnaire/interview responses are presented below, identifiers $\mathrm{B}-\mathrm{xx}, \mathrm{C}-\mathrm{xx}$ and $\mathrm{P}-\mathrm{xx}$ are used instead of their real names. B, C, P stands for the Biology, Chemistry and Physics major methods course they attended respectively.

\section{Results and Discussion}

A comparison of the features of good science teaching mentioned in the 'pre-video entry conception' and 'post video entry conception' reveals a significant growth both quantitatively (i.e., more features) and qualitatively (i.e., a more diverse range of features with greater elaboration). Approximately 50\% student teachers listed 10 or more additional features after watching the videos. This significant increment indicates that the videos and the questions set in Task 2 had acted as an effective prompt for eliciting student teachers' entry conceptions of good science teaching. For example, student teacher P-25, who only listed one feature in Task 1 ('student can understand more about the concepts of science after the class'), identified 18 features in Task 2. When asked about this substantial increase in the number of good features of science teaching, he commented: 
Questions asked in Task 2 are more concrete and specific so that I knew what I had to look for while watching the video. (P-25).

In Task 2, student teachers were asked to list the good features of the lesson and the corresponding running time of the relevant episodes. It is likely that this latter requirement encouraged them to view and judge the lessons in a more specific and detailed manner.

\section{Elements of good science teaching identified}

The good features frequently mentioned by our student teachers prior to watching of the videos fall into the following areas:

(i) explaining concepts clearly;

(ii) making good and effective use of teaching aids;

(iii) providing a good learning environment in which students of diverse characteristics are encouraged to participate, voice their opinions, ask questions, and take responsibility for their own learning;

(iv) developing students’ scientific thinking and problem solving skills; encouraging students to reason critically and think creatively;

(v) relating science content to daily life and highlighting how scientific knowledge is applied in the technological world;

(vi) involving students in more hands-on practical work and projects;

(vii) making science fun and taking account of students' interests in planning lessons;

(viii) nurturing a positive attitude towards science and developing interest in science.

After watching the videos, the number of good features increased sharply in areas (i) to (iv), but less so in area (v) to (vii). There was a significant drop (by about 50\%) in the 
total number of features mentioned in area (viii) in Task 2. It seems that student teachers concentrated on the prominent features and specific details of the particular lessons rather than thinking about the more general goals of science teaching. This shift of emphasis from a broad picture of science teaching (Task 1) to the classroom level (Task 2) was further supported by the sharp rise in the number of good features falling into the areas of classroom management and time management. They were scarcely mentioned in Task 1 but almost all student teachers identified either or both of these two areas in Task 2. The provision of the authentic classroom context stimulated them to focus on areas and issues that will soon fall onto their shoulders, and we believe this earlier 'warning' will encourage the student teachers to devote more attention to the course components that address these issues. Other features emerging in Task 2 included good question and answer skills, knowing how to motivate students, enhancing self-esteem and infusing sound moral values - again, features that were well exemplified by the teachers in the videos.

\section{Degree of video influence}

Student teachers who stated that the videos had had a 'very strong' or 'strong' influence usually generated a longer and more elaborated list of additional features in Task 2 than other student teachers, indicating that the videos were acting as an effective prompt for them. Interestingly, only three students stated that the videos only exerted a 'very weak' influence. While one of these students had no increase in the number of good features given in Task 2, the other two students showed a considerable increase, each with 8 additional features listed in Task 2. The following excerpt of interview data of student teacher, B-18, reveals the reason why she felt the videos had had very weak influence on her conception of good science teaching. 
Tutor: The influence of CD-ROM [on your conception of good science teaching] is "very weak". Why?

B-18: The good features of the lessons are those I have thought of before.

That is, the video reinforced existing views, even though they may not have been mentioned in Task 1. Although the videos did not have much effect on changing, enriching or developing this student teacher's conception, they did have the effect of eliciting, recollecting or reinforcing her existing conceptions of good science teaching. In our view, the videos served as an effective prompt for individuals to reflect on their conception of good science teaching irrespective of whether this resulted in any changes in their conception.

\section{Different kinds of video influence}

The interview data provide evidence that in addition to acting as an effective recall tool on students' existing conceptions, the videos have both reinforced and developed student teachers' conceptions of good science teaching in one or more of the following ways:

(i) recognizing exemplary practitioners in the videos as role models who can inspire them to formulate personal goals directed towards these practices;

(ii) broadening their awareness of alternative teaching methods and approaches not experienced in their own learning;

(iii) broadening their awareness of different classroom situations;

(iv) providing proof of existence of good practices;

(v) prompting them to reflect on their existing conceptions of good science teaching.

For the sake of presentational clarity, we provide representative interview excerpts to illustrate each of these five influences. However, it should be noted that these effects are often inter-related and interact with one another in influencing and developing student teachers' conceptions of good science teaching. 
(i) Exemplary practitioners as role models

One commonly emphasized advantage of the use of classroom videos in teacher education is to provide clear models of teaching by showing good implementation of them in actual classrooms (Atkin 1998, Hattfield 1996). In his study investigating whether two years in a teacher education programme makes a difference to student teachers' capacity to recognize a “good” primary science teacher, Skamp (1995) noted that because exemplary teachers are often not available, videotapes could be an option to assist student teachers to focus on criteria for good teaching. Our interview data provides evidence that even prior to formal teacher education, the opportunity of reviewing exemplary practices in science teaching can furnish student teachers with suitable role models. Several student teachers stated explicitly that they were inspired by the teachers in the videos and would like to 'follow suit'. Some student teachers had even begun to identify specific aspects of the classroom practice of the two teachers in the videos on which they might focus their attention during the course - for example, student-teacher interaction, planning to cater for the diversity in learners' ability, question and answer skills.

Since the school is at lower banding ${ }^{3}$, if I were to teach in the same kind of school, I'd like to use the same teaching method as used by the teacher in the video. I have never thought of some of his teaching skills...If my teaching is like that of the two teachers in the videos, I will be satisfied with it very much. (P-16)

If I were the teacher, once I know the student's answer is wrong, I may not have patience to listen to him and may ignore his feelings. Then I may tell the student directly that his

\footnotetext{
${ }^{3}$ Secondary schools in Hong Kong are divided into three bands based on student performance in public examinations. All students are tracked based on performance in primary schools and placed in schools with children of similar levels of performance.
} 
answer is wrong and correct his answer immediately. That's why I want to learn from the teacher in the video of his attitude in receiving students' answers. (P-11)

Several student teachers with teaching experience acquired prior to joining the programme responded similarly. For example, one of them, who had been a substitute teacher and a teaching assistant for two years, reflected critically on his own weaknesses in comparison with the good practices shown in the videos, thereby identifying teaching elements for improvement in the future:

When compared with the two teachers in the video, their lesson preparation is much better than mine. So I have to put more time into lesson preparation in the future... They can improvise questions immediately during the lesson. I think they have thought about this before the lesson. This is what I am weak in. (B-14)

However, there may also be some negative effects in terms of lowering students teachers' confidence by setting too high a standard for them at such an early stage in the course. The responses from the following two student teachers are indicative of such an influence: Lesson I is a model. But I don’t think all lessons can be like this. (C-22) I haven't encountered any teacher who is like the two in the videos. I am doubtful if I can teach so well as they do... It's really a great challenge. Do I need to train myself up to their standard? I don't know if I can do it within this year or not. (C-44)

Thus, we share Brophy's (2004) concern that novice teachers and struggling teachers need some exposure to modeling of best practice, but an exclusive focus on best practice can be daunting for them, especially if it leads them to believe that they lack what it takes to achieve that level of competence. The responses of our student teachers suggest that a range of models, representing stages in progression from novice to expert teachers, may 
be needed for teacher professional development. The goals we set for student teachers through these means should be challenging but achievable.

\section{(ii) Awareness of alternatives}

As they revealed in interview, many student teachers had experienced a fairly traditional, transmissive mode of teaching during their own schooling. The exemplary teaching demonstrated in the videos opened their eyes to a range of teaching strategies they had not previously encountered, as reflected in the following excerpt:

The two lessons give me a lot of new ideas which I haven’t thought of before...My own education was not like those in the videos. There were fewer questions, less students' participation in discussion and fewer opportunities for students to express their ideas. I just sat there and listened to what the teacher said. (C-33)

The interview data show that the performances of the teachers in the videos broadened student teachers' awareness of alternative teaching approaches and stimulated them to begin reconstructing their pedagogical knowledge. This reconstruction was a direct consequence of the student teachers perceiving the alternative approaches used by the teachers in the video as intelligible, plausible and fruitful.

In the past, not many of my classmates were willing to raise their hands to express their ideas. Actually I did have many questions in my mind during lessons, but I don't know why I did not dare to raise them with the teacher as the students in the video did. If the teacher encourages students to ask questions [as in the video], this would raise students' interest in learning. In the past, students were not so active in asking questions when compared to that in the CD-ROM. Thus, I would consider "encouraging students to ask" as a good feature. (B-05) 
Before watching the videos, I thought "stimulating students' interest" can only be achieved through activities, e.g. site-visits and discussion. I have never thought that this can be achieved through mere talking about everyday examples. What's more is that this can be done so often throughout the lesson and in an integrated manner... (B-09)

No adverse or negative feelings seem to have been generated as a result of watching the videos. In all, the differences among the student teachers' responses in this respect highlighted for us the wide variation of preconceptions and readiness for new conceptions. The data also signalled to us the need for more diverse components in our PGDE course to cater for students' experiential and conceptual differences in order to achieve optimum development for each student teacher.

(iii) Awareness of different classroom situations

Exposing the student teachers to videos of different teachers working with students from different schools served to highlight the diverse nature of students, with a consequent awareness of the need to cater for students' differences. Some student teachers, particularly those coming from high banding schools, may have underestimated the difficulty of motivating students of lesser academic abilities and have given insufficient thought to ways of arousing students' interest or maintaining class discipline:

I can see that it's very difficult to exert control of the class in the second video. It gives me a warning that my future students may be like that. (B-07)

Teachers in my school taught rather differently from those in the videos, as my class had a good academic performance. The teachers just taught clearly. I know little about students with low learning abilities, like those in the videos. So I was quite bored by the teaching in the video at the beginning. I just wondered why the teaching for these 
students was like that. It seemed boring. But later I realized that such teaching methods can arouse students' interest and facilitate their learning. (B-13)

On the other hand, when seeing enthusiastic students, some student teachers started to realize the demanding nature of teaching and its complexity and immediacy, as one of them put it:

The response of students to the experiments was great. I was surprised by the answers they put forward to explain the experimental results....In the video, the questions raised by the students were very challenging. The teacher could answer the questions immediately, clearly and thoroughly. The immediate response of the teacher is very important. I have never considered this before. There is much to be learnt. Before watching, I think it's very easy to answer students' questions. But after that, I am surprised that junior secondary students nowadays can ask such challenging questions and have a great desire for knowledge. (C-44)

(iv) Proof of existence of good practices

The videos provide a demonstration of good practices, and so encourage student teachers to try out those practices in their future teaching. Some student teachers had thought that these teaching methods are impractical, but their view changed when they saw successful implementation of the methods in real classroom settings via the videos. This impact is similar to that of confronting students' learning scientific concepts with observations that conflict with their preconceptions, thereby putting them in cognitive disequilibrium. Novel practices and those that initially seem unworkable are more likely to be attempted when student teachers can see clear evidence that they are both 'plausible' and 'fruitful', as revealed in the following interview excerpts: 
Before watching the videos, I actually had some ideas about teaching but I wasn't sure if they would work or not... Now, it's cleared up my mind and let me know that the ideas are practical and possible. (C-35)

I had never thought of introducing the practical in such a way. That is, asking students to read about the experimental procedures on their own and then let them raise questions with the teacher... I had never thought it would work before, as I thought students would just become off task during the reading time...The videos show me that some teaching methods do work. (B-13)

Some features have had a great impact on me, especially those I haven't experienced and seen before. Before that, I just thought that those features might not be practical. For example, in Lesson II, the teacher kept on asking students questions throughout the lesson. The teaching format was question-based. It's a new idea which impacted on me most. But it’s much more difficult to teach in such a way than in the traditional one. (B-06)

In excerpt (B-06), the student teacher clearly accepts questioning of students as an effective teaching-learning strategy, but he is worried about the difficulties of implementing it. Even this seemingly tentative position is a significant advance on his previous view that it is simply impractical. Proof of existence of good practices is especially important for student teachers because it means they cannot hide behind the smokescreen of perceived implausibility.

\section{(v) Promoting reflection}

The videos stimulated some student teachers to reflect on the quality of teaching they experienced in their own schooling, an exercise that helps to promote reformulation of their conceptions of good and bad science teaching. 
Because of the videos, I became aware of the negative side of my secondary education...I thought that it's just normal to receive that kind of teaching. But after I have watched the videos, I realized that the teaching in my secondary school was rather poor... Since I had never experienced the kind of teaching demonstrated in the videos, I didn't realize what is meant by “Good Science Teaching”. (P-03)

The videos have also helped student teachers to become aware that teaching is not a simple straightforward task. Awareness of the complexity of teaching resulted in concerns among some student teachers about students with strikingly different learning abilities, the constraints imposed by an overcrowded curriculum, insufficient time and inadequate resources and facilities, and the need for continual decision-making and immediate response to critical incidents. These concerns have activated some student teachers to question, reflect on and restructure their conceptions in search of solutions to the various complex situations they are likely to face in their future teaching.

The videos made me realize that different teaching methods should be used for different kinds of students. For example, for the unmotivated, competition, games, interesting stories, etc. can be used to arouse their interest. But for the motivated higher achievers, there should be fewer games but more new information about the concepts. These should be varied according to the types of student. (B-13)

The girl's answer was very long indeed. When I was watching that particular episode, I was wondering whether it's good or not for the teacher to ask the girl to repeat such a long answer to the class. I mean, if the class really pays attention to her it'd be good if she says it again. But what if class order is not kept? You know, I was struggling between two choices: (1) the teacher repeated the answer for the girl, or (2) the teacher let the girl repeat the answer herself. Thus I rewound and reviewed this part of the video again... I appreciate so much how the teacher dealt with the situation [The teacher in the video 
made very skilful use of this incident to teach students to respect each other by paying attention when others are speaking]. (P-21)

I repeatedly rewound and reviewed a particular episode several times...The teacher used a simile to explain a complicated and abstract theory... He might have explained something wrong to the students though he also explained to the students that the theory is so complicated that they might not be able to understand at this stage, and that's why he used this simile to explain, although it was partially wrong. When I watched this episode, I imagined myself as the teacher and thought about whether this explanation was OK, whether my students would accept it and whether other teachers would consider I have taught something wrong to my students. Although such a simplification makes students understand easily, a wrong concept is introduced. Is this acceptable? (P-14)

As evident from the last two excerpts, unlike live observations, videos allow for multiple and repeated opportunities to re-play, analyze and re-analyze the same episode. They also provide the opportunity to delve into the fast-paced, complicated world of classroom teaching. Clearly, viewing classroom interactions via video is an opportunity for reflection. Most importantly, this reflection can take place amongst student teachers even before the course formally starts.

\section{Unanticipated Outcomes}

In their report on using a series of videocases in elementary science teacher preparation, Abell and Cennamo (2004) acknowledge that a considerable amount of class time is needed for integration into a course, and instructors who use videocases must decide what to cut from an existing course to make space for the videocase-based teacher education. They dealt with this challenge, in part, by reconceptualizing their elementary science methods course towards a reflection orientation (Abell and Bryan 1997). In our study, we 
have seen that the use of videos in pre-service teacher education can be very fruitful in extending learning time beyond normal class contact hours. This also allows greater flexibility for student teachers to watch the videos at their own pace, and to absorb ideas captured in the videos, as reflected in the following comments:

I had some feelings when I watched some episodes. But I was not sure what the feeling was so I watched them again. Just like watching film, you will discover and understand more when watching it the second time. So, this is just like teaching. Students will learn more if the teaching time is doubled. (C-04)

I could think in detail when doing Task 2 at home. I could watch the videos several times as time allowed me to do so. That's why the effect of the videos on my views of good science teaching is "strong”. (C-33)

It is interesting to note that several student teachers watched the videos alongside their close relatives or friends, and shared their thoughts and responses with them, as exemplified in the excerpt below. This is clearly a source of additional insight and suggests to us that more substantial and significant conceptual change may be achieved if students are encouraged to watch the videos in small groups.

I didn't have many ideas when doing Task 2 . My aunt, who is a primary school teacher, watched the video as well. She suggested a point to me - give students clear instructions before doing experiments, which I didn’t notice myself before. (B-04)

This excerpt provides evidence that strategies for bringing about conceptual change could be made more effective by incorporating the social aspects of learning - echoing Solomon's (1987) insistence on greater prominence for the social dimension in the learning of science. 
Because the two lessons in the videos are taught by different teachers the student teachers tended to compare the style, attitude and teaching approaches of the two teachers. It is evident from the interview data that the opportunity to make comparisons gives rise to more elaborated conceptions - a finding that prompts speculation about the optimum number of teachers to feature in the videos.

I did compare the two lessons. Actually I watched Lesson II first and I thought that it's very good. But after watching Lesson I, I felt that Lesson II was not as good as I thought... However, overall the teacher of Lesson II was better. One will get more feelings if he can watch more lessons. (B-09)

One of the important goals of teacher education is to help student teachers to act like professional teachers. To act like a teacher, they have to first perceive themselves to be a teacher. The videos seem to have acted as a catalyst to socialize the student teachers into the role of being a teacher. In a sense, pre-entry video reviewing has got them ready to 'think like a teacher' and to begin to be cognizant of the complex ways in which the actions of teachers impact on their students.

The impact of the videos is "strong", as they grab my attention on the features which I haven't noticed before. In the past, when I was a student, I was a receiver and just noticed what was taught. Now, I am an observer, watching how a teacher should teach. (P-05)

In the past, I was a student who was a receiver of education. I only paid attention to the teacher but never thought about how the ways s/he taught would affect me. But now, when watching the video, I, being a third party, am concerned with how the teacher teaches and the response of students as well. This is why the videos have had an impact on my views of good science teaching. (B-21) 
It is becoming increasingly apparent from comments such as these that effective use of videos beyond class time, and particularly prior to formal instruction, helps to speed up the process of enculturation of our student teachers into the teaching profession.

A particularly important yet unanticipated outcome of the project was that the interviews with our students prior to the formal instruction have given us both an understanding of their prior conceptions of good science teaching and a sense of how their past experiences, hopes and fears have influenced those conceptions. In addition, the lengthy dialogue demanded by the research methods established an effective communication channel with our students from the outset, encouraging them to seek advice more readily and to communicate with us more comfortably outside class time.

\section{Implications for the use of video in teacher education}

This study has a number of implications for our future production and use of videos in developing student teachers' conceptions of good science teaching. For example, to avoid demotivating student teachers by showing only the consistently high standard of exemplary teaching, a range of competencies corresponding to various stages of professional development will be included in the videos. Provided that some ethical issues can be resolved, our own teacher training programme graduates constitute a suitable pool, particularly since the level of competency demonstrated would serve as a concrete guide to the sort of competency to which beginning student teachers can aspire. Nonetheless, we are reminded of Seago’s (2004) concern about teacher educators rushing to use videos of classrooms without careful consideration of what it might mean to the teachers and the students in the videos, as well as the future willingness of teachers to open their classroom for teacher professional development. This is especially true for 
beginning teachers whose confidence can be quite fragile. This reminds us to pay more attention to the motivational aspects of learning.

Reviewing similar teaching episodes involving different teachers can encourage deeper analysis of good practice and stimulate more in-depth reflection on student teachers' own conceptions of good science teaching. We intend to investigate the optimum number of exemplar teachers for comparisons of good teaching, taking into account what constitutes a reasonable total time for reviewing. It almost goes without saying that episodes showing classrooms and students of a more diverse nature will help student teachers to prepare for facing classroom situations not previously encountered in their past schooling, or even envisaged. Videos of mainstream classroom teaching are effective in drawing student teachers' attention to common issues and problems faced by teachers, and illustrating teaching strategies and skills commonly employed to achieve standard educational goals; they can also be effective in alerting student teachers to nontraditional approaches.

Lastly, as noted by several authors in a review on using video in teacher education (Brophy, 2004), video is a technology, not a curriculum in itself. Hence, if videos are to be used effectively as teacher education tools, both the videos themselves and the learning activities in which they are embedded must be selected or developed with specific learning goals in mind. Findings of the present study point to the use of authentic classroom videos as an effective prompt for eliciting student teachers' conceptions of good science teaching prior to formal instruction. However, more work remains to be done in determining how student teachers can be taught and helped to exploit the advantages of video technology in uncovering, clarifying, developing and refining their conceptions of good science teaching. This work would be particularly helpful to those students whose conceptions were not elicited by or substantially enriched by viewing the 
videos. Such endeavours involve encouraging student teachers to 'dig deeply', asking them not only what they notice in the videos, but on a "meta-level," why it is they notice those features. For instance, “what is of interest to you about that?" and "why is that important to you?" Such questions can help student teachers to move to the meta-level of considering why they are inclined to look for particular aspects of practice, and can stimulate them to examine the beliefs and assumptions that underlie their attention to these features. We see this uncovering of personal beliefs as an important part of the professional development of our student teachers. Indeed, we believe that what one pays attention to in videos can be a clear signal of one's underlying theories and beliefs. At present, this is an under-researched area.

\section{Concluding Remarks}

It seems that the use of videos has enabled us to make a good start in setting the stage for our student teachers to develop their conceptions of good science teaching. The next stage of research is to track how our student teachers' conceptions of good science teaching evolve during the various stages of our teacher education programme - for example, before and after periods of teaching practice - and how each component of our course has influenced student teachers' conceptions. These results will provide us with information on how to best tailor our course to achieve our programme goals and will provide some baseline data for future longitudinal studies of a particular group of student teachers as they proceed through the different stages of professional development.

\section{Acknowledgement}


The research reported in this article was supported by a CRCG Research Grant of The University of Hong Kong (10205178/21111/10000/323/01). The authors are grateful to the student teachers who kindly agreed to take part in the study.

\section{References}

Abell, S.K., Bryan, L.A. and Anderson, M A. (1998). Investigating preservice elementary science teacher reflective thinking using integrated media case-based instruction in elementary science teacher preparation. Science Education, 82, 491-510.

Abell, S.K. and Cennamo, K. (2004). Videocases in elementary science teacher preparation. In ,J. Brophy (ed.) Advances in Research on Teaching, vol. 10: Using Video in Teacher Education (Amsterdam: Elsevier), 103-129.

Abell, S. K. and Bryan, L. A. (1997). Reconceptualizing the elementary science methods course using a reflection orientation. Journal of Science Teacher Education, 8(3), 153-166.

Anderson, R.D. (1997). The science methods course in the context of the total teacher education experience. Journal of Science Teacher Education, 8(4), 269-282.

Atkins, S.L. (1998). Windows of opportunity. Preservice teachers perceptions of technology-based alternatives to field experiences. Journal of Computers in Mathematics and Science Teaching, 17, 95-105.

Barone, T., Berliner, D.C., Blanchard, J., Casanova, U. and McGowan, T. (1996) A future for teacher education. In J. Sikula (ed.) Handbook of Research on Teacher Education (2 ${ }^{\text {nd }}$ ed.) (New York: Macmillan), 1108-1149.

Bencze, L., Hewitt, J. and Pedretti, E. (2001). Multi-media case methods in pre-service science education: Enabling an apprenticehip for praxis. Research in Science Education, 31(2), 191-209. 
Bencze, L., Hewitt, J., Pedretti, E., Yoon, S., Perris, K. and van Oostveen, R. (2003). Science-specialist student-teachers consider promoting technological design projects: Contributions of multi-media case methods. Research in Science Education, 33(2), 163-187.

Black, P. and J. M. Atkin (eds.) (1996). Changing the Subject: Innovations in Science, Mathematics and Technology Education (London: Routledge).

Boulton-Lewis, G. M., Smith, D. J. H., McCrindle, A. R., Burnett, P. C. and Campbell, K. J. (2001). Secondary teachers' conceptions of teaching and learning. Learning and Instructions, 11, 35-51.

Broadfoot, P. (1992). Teaching and the challenge of change: Educational research in relation to teacher education. European Journal of Teacher Education, 15(1-2), 45-52.

Brophy, J. (ed.) (2004) Advances in Research on Teaching, vol. 10: Using Video in Teacher Education (Amsterdam: Elsevier).

Bryan, L.A. and Abell, S.K. (1999). Development of professional knowledge in learning to teach elementary science. Journal of Research in Science Teaching, 36(2), 121139.

Calderhead, J. and Robson, M. (1991). Images of teaching: Student teachers’ early conceptions of classroom practice. Teaching and Teacher Education, 7, 1-8.

Carter, K. (1993). The place of story in the study of teaching and teacher education. Educational Researcher, 22, 5-12, 18.

Clark, C.M. (1988). Asking the right questions about teacher preparation. Contributions of research on teaching thinking. Educational Researcher, 17(2), 5-12.

Cochran-Smith, M. (2003). Inquiry and outcomes: Learning to teach in the age of accountability. Teacher Education Practice, 15(4), 12-34. 
Colburn, A. and Tillotson, J.W. (1998). A case study for use in science methods courses. Journal of Science Teacher Education, 9(2), 153-164.

Copeland, W. and Decker, D. (1996). Video cases and the development of meaning making in preservice teachers. Teaching and Teacher Education, 12(5), 467-481.

Crooks, C. and Gifford, V.D. (1992). A comparison of videotaped teaching models and the lecture technique in increasing the use of questioning strategies presented in elementary science lessons. Journal of Science Teacher Education, 3(3), 76-78.

Driver, R., Guesne, E., and Tigerghien, A. (1985). Children's Ideas in Science (Milton Keynes: Open University Press).

Duit R. and Treagust D. F. (2003). Conceptual change: a powerful framework for improving science teaching and learning. International Journal of Science Education, 25(6), 671-688.

Gao, L. B. and Watkins, D. (2002). Conceptions of teaching held by school science teachers in P.R. China: identification and cross-cultural comparisons. International Journal of Science Education, 24(1), 61-79.

Gow, L. and Kember, D. (1993). Conceptions of teaching and their relationship in student learning. British Journal of Educational Psychology, 63, 20-33.

Gunstone, R. F., Slattery, M., Baird, J. R. and Northfield, J. R. (1993). A case study exploration of development in preservice science teachers. Science Education, 77, 47-73.

Greenwood, G.E. and Parkay, F.W. (1989). Case Studies for Teacher Decision Making (New York: Random House).

Harrington, H.L. (1995). Fostering reasoned decisions: Case-based pedagogy and the professional development of teachers. Teaching and Teacher Education, 11(3), 203-214. 
Hattfield. M. M. (1996). Using multimedia in preservice education. Journal of Teacher Education, 47(3), 223-228.

Hewitt, J., Pedretti, E., Bencze, L., Vaillancourt, B.D. and Yoon, S. (2003). New applications for multimedia cases. promoting reflective practice in preservice teacher education. Journal of Technology and Teacher Education, 11(4), 483-500.

Hewson, P.W. (1981). A conceptual change approach to learning science. European Journal of Science Education, 3(4), 383-396.

Hewson, P.W. and Thorley, N.R. (1989). The conditions of conceptual change in the classroom. International Journal of Science Education, 11, 541-553.

Hoy, A.W. and Murphy, P.K. (2001). Teaching educational psychology to the implicit mind. In B. Torff \& R.J. Sternberg (eds.) Understanding and Teaching the Intuitive Mind: Student and Teacher Learning (Mahwah, NJ: Lawrence Erlbaum Associates), 145-185.

Kember, D. (1997). A reconceptualisation of the research into university academics' conceptions of teaching. Learning and Instruction, 7(3), 255-275.

Koballa, T. and Tippens, D. (2000). Cases in Middle and Secondary Science Education: The Promise and Dilemmas (Columbus, OH: Merrill Prentice Hall).

Koballa, T. and Tippens, D. (2004). Cases in Middle and Secondary Science Education: The Promise and Dilemmas ( $2^{\text {nd }}$ ed.) (Columbus, OH: Merrill Prentice Hall).

Korthagen, F. and Kessels, J. (1999). Linking theory and practice: Changing the pedagogy of teacher education. Educational Researcher, 28(4), 4-17.

Kowalski, T.J., Weaver, R.A. and Henson, K.T. (1990). Case Studies on Teaching (New York: Longman).

Lave, J. and Wenger, E. (1991). Situated learning: Legitimate peripheral participation (Cambridge: Cambridge University Press). 
Levin, B.B. (1995) Using the case method in teacher education: The role of discussion and experience in teachers' thinking about cases. Teaching and Teacher Education, 11(1), 63-79.

Louden, W. and Wallace, J. (1996) Quality in the Classroom: Learning about Teaching through Case Studies (Rydalmere, NSW: Hodder).

Marx, R., Blumefeld, P., Krajcik, J and Soloway, E. (1998). New technologies for teacher professional development. Teaching and Teacher Education, 14(1), 33-52.

Merseth, K.K. (1991). The early history of case-based instruction: Insights for teacher education today. Journal of Teacher Education, 42(4), 243-249.

Munby, H., Cunningham, M. and Lock, C. (2000). School science culture: A case study of barriers to developing professional knowledge. Science Education, 84(2), 193211.

Osborne, R., and Freyberg, P. (1985). Learning in science: The implications of children's science (Auckland: Heinemann).

Pintrich, P. R., Marx, R. W., and Boyle, R. A. (1993). Beyond cold conceptual change: The role of motivational beliefs and classroom contextual factors in the process of conceptual change. Review of Educational Research, 63(2), 167-199.

Posner, G.J., Strike, K.A., Hewson, P.W., and Gertzog, W.A. (1982). Accommodation of a scientific conception. Toward a theory of conceptual change. Science Education, 66(2), 211-227.

Putnam, R.T. and H. Borko (1997). Teacher Learning: Implications of New Views of Cognition. In B. Biddle, T. L. Good and I. F. Goodson (eds.) International Handbook of Teachers and Teaching, Vol. II (Dordrecht: Kluwer Academic Publishers), 1223-1296. 
Putman, R.T. and Borko, H. (2000). What do new views of knowledge and thinking have to say about research on teacher learning? Educational Researcher, 29(1), 4-15.

Rodriguez, A.J. (1998). Strategies for counter resistance: Toward sociotransformative constructivism and learning to teach science for diversity and for understanding. Journal of Research in Science Teaching, 35(6), 589-622.

Rogoff, B. (1990). Apprenticeship in Thinking: Cognitive Development in Social Context (Oxford: Oxford University Press).

Roth, W-M, Masciotra, D. and Boyd, B. (1999). Becoming-in-the classroom: A case study of teacher development through coteaching. Teaching and Teacher Education, 15(7), 771-784.

Rubba, P.A. (1992). The learning cycle as a model for the design of science teacher preservice and inservice education. Journal of Science Teacher Education, 3(4), 97-101.

Sanger, J. (1990). Awakening a scream of consciousness: The critical group in action research. Theory into Practice, 29(3), 174-178.

Schön, D. (1983). The Reflective Practitioner: How Professionals Think in Action (New York: Basic Books).

Seago, N. (2004). Using video as an object of inquiry for mathematics teaching and learning. In J. Brophy (ed.), Advances in Research on Teaching, vol. 10: Using video in teacher education (Amsterdam: Elsevier), 259-286.

Sherin, M. G. and Han, S. Y. (2004). Teacher learning in the context of a video club. Teaching and Teacher Education. 20(2), 163-183.

Silverman, R., Welty, W.M. and Lyon, S. (1996). Case Studies for Teacher Problem Solving (New York: McGraw-Hill). 
Skamp, K. (1995). Student teachers' conceptions of how to recognise a "good” primary science teacher. Does two years in a teacher education program make a difference? Research in Science Education, 25(4), 395-429.

Solomon, J. (1987). Social influences on the construction of pupils' understanding of science. Studies in Science Education, 14, 63-82

Tobin, K. and Fraser, B.J. (1989). Case studies of exemplary science and mathematics teaching. School Science and Mathematics, 89(4), 320-334.

van den Berg, E. (2001). An exploration of the use of multimedia cases as a reflective tool in teacher education. Research in Science Education, 31(2), 245-265.

Wilson, S.M. and Berne, J. (1999). Teacher learning and the acquisition of professional knowledge: An examination of research on contemporary professional development. In Iran-Nejad, A. and Pearson, P.D. (eds.), Review of Research in Education, 24, 173-210

Yung, B.H.W., Wong, S.L. and Cheng, M.W. (2003) A curriculum innovation. Focusing on student teachers' developing conceptions of good science teaching. AsiaPacific Forum on Science Learning and Teaching, 4(2), [Online] http://www.ied.edu.hk/apfslt/

Zeichner, K.M. and Gore, J.M. (1990) Teacher socialization. In Houston, W.R. (ed.) Handbook of Research on Teacher Education (New York: Macmillan), 320-347 


\section{Task 1}

\section{What Is Good Science Teaching - Entry Conception}

We are not looking for the 'right' answers from you. In fact, people often disagree on what exactly good science teaching is. We are just interested to know about what you think, YOUR views and how YOUR views have changed over time, and what are the factors that have influenced and shaped your views.

\section{Section A - Background information}

1. Name .

2. Sex . $\quad$ Male $\square \quad$ Female $\square$

3. Highest qualification attained $\operatorname{PhD} \square \quad$ Master $\square \quad$ Bachelor $\square$

4. Major subject in undergraduate. Physics $\square \quad$ Chemistry $\square \quad$ Biology $\square$ Others (please specify)

5. Major subject in PGDE. . Physics $\square$ Chemistry Biology

6. Teaching experience (years) . 0 (excluding private tuition)

\section{Section B - What is good science teaching}

1. How do you feel about the science education that you received in:

a. primary level very poor poor satisfactory good excellent

b. junior secondary

$\begin{array}{ll}\square & \square \\ \square & \square \\ \square & \square \\ \square & \square\end{array}$

d. tertiary level

2. In your opinion, what is good science teaching? List as many features as possible. 
Task 2

Appendix II

My Views on the Science Lessons - On Entry

Name. PGDE Major. Physics $\square$

Chemistry

Biology

\section{Instruction}

Please watch the videos of the two science lessons in the CD-ROM and respond to the questions below.

\section{Lesson 1 - Density (40 min)}

1. List the good features of the lesson and the corresponding running time of the relevant episodes e.g. 3'25” to 5'. (Please type below)

2. List the areas that you think the lesson can be improved and the corresponding running time of the relevant episodes. (Please type below)

\section{Lesson 2 - Boiling point of water $(20 \mathrm{~min})$}

1. List the good features of the lesson and the corresponding running time of the relevant episodes. (Please type below)

2. List the areas that you think the lesson can be improved and the corresponding running time of the relevant episodes. (Please type below)

\section{Other essential features of good science teaching}

List other essential features of good science teaching that you have not mentioned above. (Please type below)

Please indicate the effect of each of the following factors in influencing your views about good science teaching. ( 1 - very weak, 2 - weak, 3 - moderate, 4 - strong, 5 -very strong)

\begin{tabular}{|l|l|l|l|l|l|}
\hline Factors & $\mathbf{1}$ & $\mathbf{2}$ & $\mathbf{3}$ & $\mathbf{4}$ & $\mathbf{5}$ \\
\hline Primary education & & & & & \\
\hline Junior Science education & & & & & \\
\hline Senior Science education & & & & & \\
\hline Tertiary education & & & & & \\
\hline The videos of the 2 lessons in the CD-ROM & & & & \\
\hline
\end{tabular}

List other factors which have influenced your views about good science teaching but not mentioned above. (Please type below) 